\title{
A review of strategies aimed at adapting livestock to volatile climatic conditions
} in Nigeria

Oyeniyi, F. G. and Ewuola, E. O.

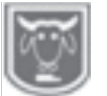

Animal Physiology and Bioclimatology Unit, Department of Animal Science, Faculty of Agriculture, University of Ibadan, Oyo State, Nigeria

Abstract

Despite their crucial importance, limited information exists about how livestock are affected by climate change in Nigeria. Changing climatic patterns are manifested through occurrences like abrupt temperature increase, dwindling rainfall pattern, rise in spells of drought and flood. These conditions exert different effects across the geographical landscape of the country, which can broadly be classed as Semiarid, Sahel and Derived Savannah, respectively as well as Forest and Montane. Livestock provide humans with the full complement of amino acids, which are the only known natural suppliers of Vitamin $B_{12}$ and equally supply iron, calcium, iodine and zinc. In addition, livestock accounts for $40 \%$ of Agricultural Gross Domestic Product and significantly contributes to enhancing rural livelihood. Stress conditions are induced in livestock by harsh weather conditions that reduce the feed available to them as well as impede growth rate and reproduction efficiency and disease incidence which may eventually result in death. In the light of the livestock benefits to humanity, it is necessary to devise means of making their climate resilient. Some of the proven strategies include animal genetic improvement for stress tolerance, growing disease resistant, early maturing and drought tolerant crops, selecting for and rearing climate tolerant animal species and breeds.

Keywords: Adapt, Livestock, Climate, Stress, Strategies

\section{Un examen des stratégies visant à adapter le bétail aux conditions climatiques volatiles au Nigéria}

\section{Résumé}

Malgré leur importance cruciale, il existe peu d'informations sur la manière dont le bétail est affecté par le changement climatique au Nigéria. Le changement des modèles climatiques se manifeste par des événements tels que l'augmentation brutale de la température, la diminution des précipitations, l'augmentation des périodes de sécheresse et d'inondation. Ces conditions exercent des effets différents sur le paysage géographique du pays, qui peuvent être globalement classés comme semi-aride, sahélien et savane dérivée, respectivement, ainsi que forêt et montagne. Le bétail fournit aux humains le complément complet d'acides aminés, qui sont les seuls fournisseurs naturels connus de vitamine B12 et fournissent également du fer, du calcium, de l'iode et du zinc. En outre, l'élevage représente $40 \%$ du produit intérieur brut agricole et contribue de manière significative à l'amélioration des moyens d'existence ruraux. Les conditions de stress sont induites chez le bétail par des conditions météorologiques difficiles qui réduisent les aliments disponibles pour eux et entravent le taux de croissance, l'efficacité de la reproduction et l'incidence des maladies qui peuvent éventuellement entraîner la mort. À la lumière des avantages de l'élevage pour l'humanité, il est nécessaire de concevoir des moyens de rendre leur résilient climatique. Certaines des stratégies éprouvées comprennent l'amélioration génétique animale pour la tolérance au stress, la culture de cultures résistantes aux maladies, à maturation précoce et à la sécheresse, la sélection et l'élevage d'espèces et de races animales tolérantes au climat.

Mots clés: Adaptation, Bétail, Climat, Stress, Stratégies 


\section{Introduction}

The livestock sub-sector of the Agricultural Industry in Nigeria is affected by changing climatic conditions and other environmental hazards within all the ecological regions in the country. These conditions are hazardous and include but not limited to late onset of rainy season, higher than normal temperatures, flooding, salt water intrusion and windstorms. Late onset of the rainy season causes a lack of available water for livestock and reduces forage availability. Higher than normal temperatures leads to poor livestock health which reduces the market value of affected livestock thereby reducing farmers' income. Flooding leads to loss of livestock, destruction of livestock enclosures and outbreak of diseases. Windstorms impact fodder crops for livestock. Salt water intrusion leads to decline in livestock production as quality of fodder becomes poor due to salt water (Scholes, 1990,1993). This sub-sector is vulnerable to climate change hazards because livestock farmers in Nigeria are dependent on water to provide sufficient quantity and quality of fodder from rangeland and to provide drinking water for livestock. The high levels of poverty among livestock farmers and lack of economic alternatives for farmers and their household members combine to enhance the vulnerability of the livestock sub-sector. The main economic impact of climate change on livestock production is the loss of income that sustains pastoral livelihoods. Men are predominantly involved in livestock production therefore they have greater vulnerability to climate change impacts. However women are also affected because of their role in marketing milk products and indirectly through loss of family income from livestock. Despite the low adaptive capacity of livestock farmers to the impacts of climate change, historically, they have developed strategies to cope with and adapt to a region characterized by a variable climate. Communities dependent on livestock have over time faced harsh changes in environmental conditions and are therefore aware of the need to adopt different types of coping and adaptation strategies. These strategies include the use of forage obtained from hedgerows and compound farms, application of herbs to livestock diseases, migration of male and female youth to cities in search of jobs, drilling boreholes and water harvesting (e.g. from zinc roofs).

\section{The debacle and likely prognosis}

The livestock sub-sector is particularly susceptible to climate change due to the extent that livestock depend on water for survival. Shortage of rainfall, late onset of rains and rising temperature in the Sahel and Savanna will result in declining livestock production and productivity as well as increased incidence of diseases. In the Rainforest and Coastal zones, flooding and erosion will displace livestock farmers, destroy their assets and increase disease infestation in livestock farms. This trend will ultimately reduce animal protein supply in the country as much of the livestock production in Nigeria comes from these regions.

In the livestock subsector, the reduction of climate-related risks and adaptation to climate change will not be easy and will require long-term approaches unless a radical shift from current cultural norms of livestock management is introduced. Firstly, rangeland overgrazing and degradation must be halted and reversed to allow for recovery to full production potential. Planned and controlled range management programmes must be implemented, with grazing areas realistically divided into manageable blocks that allow for rotational grazing with managed rest periods. Re-seeding with palatable grass species will be required in some places with due consideration for 
likely competition with the native grass species and suitability for erosion control. Over the short term, interventions which reduce pressure on the rangelands will be required, such as fodder production and preservation, and the use of other supplementary feeds. A fodder production scheme could be introduced and encouraged on crop farm lands to boost livestock feed supplies and to relieve pressure on the local rangelands Fodder species could include dual purpose (foodfeed) crops such as legumes, and sorghum, rather than only planting fodder for animals as these will be more attractive to farmers (Agyemang, 2010). Whilst indigenous cattle breeds are well suited to the current and future climate, livestock owners require basic training in herd management to optimize the breeds' genetic potential, such as introducing seasonal mating systems, providing for suitable weaning times, culling unproductive animals, and maintaining a manageable animal health programme year-round. Veterinary extension services should be made available. Development of abattoir facilities in towns would be in of support for planned culling programmes. Alternative livestock production such as intensive pig and poultry production schemes in the rural areas are desirable climate risk adaptation option, since no rangeland is and the animals are housed and thus protected from the elements.

Crop-Livestock integration can be an economically viable and environmentally sustainable option for climate change adaptation if introduced properly. For example, it is recommended that instead of introducing Irish potatoes (plant tops and vines do not have much feeding value for livestock), sweet potatoes should be encouraged (vines and leaves are used for feeding livestock) and legume introduction should not be limited to Pinto beans, but should also include dual purpose (food- feed) cowpea varieties to serve both household food security and livestock fodder needs. Any proposed drought resistant crop/tree species should try to consider dual purpose (food-feed) varieties. There is currently no policy framework programme for breeding and developing animals that are better adapted to climate changes such as heat, drought and high humidity. This problem needs to be addressed at a national level.

\section{Existing governance, policies and programs}

The recommendations for federal, state and local government and the private sector for improving livestock production are outlined in Agriculture in Nigeria: FMARD, 2000; Manyong et al., 2003). If implemented, these recommendations could make an important contribution to climate change adaptation in the agriculture sector.

The following adaptation actions are recommended for the livestock sub-sector:

Intensive livestock keeping: Keeping livestock in a confinement instead of free range (extensive) will help farmers adapt to climate change impacts like disease infestation. Government, private sector, and NGOs can help livestock farmers adapt to climate change by providing soft loans needed to initiate intensive livestock production.

Planting trees near livestock houses and on pasture land: This strategy will help farmers adapt to severe windstorms which are responsible for destruction of livestock houses and forage land.

Planting trees near livestock houses and on pastureland: This strategy will help farmers adapt to severe windstorms which are responsible for destruction of livestock houses and forage land.

Greater support for insurance: Government should increase support for the Nigerian Agricultural Insurance Scheme and farmers should be encouraged to register with the 


\section{Oyeniyi and Ewuola}

Table 1: Hazard- impact-vulnerability-adaptation matrix for livestock sub-sector

\begin{tabular}{|c|c|c|c|}
\hline $\begin{array}{l}\text { Climate Change } \\
\text { Impacts }\end{array}$ & Climate Hazard & $\begin{array}{l}\text { Determinants of } \\
\text { Vulnerability }\end{array}$ & Adaptation Options \\
\hline $\begin{array}{l}\text { Eco-zone- } \\
\text { Coastal/Rainforest } \\
\text { Late onset \& early } \\
\text { cessation of rainy } \\
\text { season } \\
\text { Rising poor livestock } \\
\text { health which reduces } \\
\text { market value of } \\
\text { affected livestock } \\
\text { Reduced farmers' } \\
\text { income and reduction } \\
\text { in livestockproduction } \\
\text { Destruction of fodder } \\
\text { crops and livestock } \\
\text { houses } \\
\text { Sea level rise }\end{array}$ & $\begin{array}{l}\text { Lack of availability } \\
\text { of water for livestock } \\
\text { Reduced forage } \\
\text { availability } \\
\text { Disease outbreaks and } \\
\text { loss of pasture land } \\
\text { from flooding \& } \\
\text { erosion }\end{array}$ & $\begin{array}{l}\text { High dependence on } \\
\text { water for livestock } \\
\text { production } \\
\text { Poverty }\end{array}$ & $\begin{array}{l}\text { Rainwater harvesting, } \\
\text { digging of boreholes, } \\
\text { use of forage obtained } \\
\text { from hedgerows \& } \\
\text { compound farms, } \\
\text { intensive livestock } \\
\text { management } \\
\text { Use of ethno- } \\
\text { botanicals in treating } \\
\text { livestock diseases, } \\
\text { Building of culverts, } \\
\text { Quarantine } \\
\text { Planting of trees to } \\
\text { serve as windbreaks }\end{array}$ \\
\hline $\begin{array}{l}\text { Ecozone - Savannah } \\
\text { Late onset and early } \\
\text { cessation of rain } \\
\text { Rise in temperature } \\
\text { Occasional increase } \\
\text { in rainfall intensity }\end{array}$ & $\begin{array}{l}\text { Reduced fodder } \\
\text { production, heat } \\
\text { stress, loss of pasture } \\
\text { Heat stress, high } \\
\text { disease burden, loss } \\
\text { of pasture } \\
\text { Outbreak of diseases } \\
\text { like foot rot, } \\
\text { destruction of } \\
\text { livestock houses, } \\
\text { flooding }\end{array}$ & $\begin{array}{l}\text { Poverty } \\
\text { Dependence on } \\
\text { livestock production }\end{array}$ & $\begin{array}{l}\text { Feed } \\
\text { supplementation, } \\
\text { shift to crop } \\
\text { production especially } \\
\text { to production of } \\
\text { drought tolerant crops } \\
\text { like millet and maize, } \\
\text { drill boreholes, } \\
\text { water harvesting } \\
\text { (zinc roofs) } \\
\text { Intensive livestock } \\
\text { management, } \\
\text { Migration to Fadama } \\
\text { sites where there is } \\
\text { moisture }\end{array}$ \\
\hline & & & $\begin{array}{l}\text { Use of ethno- } \\
\text { medicine to treat } \\
\text { animals, } \\
\text { diversification into } \\
\text { mixed farming }\end{array}$ \\
\hline $\begin{array}{l}\text { Eco-zone - Sahel } \\
\text { Late onset of rain } \\
\text { Rise in temperature }\end{array}$ & $\begin{array}{l}\text { Drought and } \\
\text { desertification } \\
\text { More frequent } \\
\text { droughts, heat stress } \\
\text { and increased incidence } \\
\text { of diseases }\end{array}$ & $\begin{array}{l}\text { Lack of weather } \\
\text { forecasting resources } \\
\text { Poverty }\end{array}$ & $\begin{array}{l}\text { Migration to Fadama } \\
\text { sites where there is } \\
\text { moisture }\end{array}$ \\
\hline
\end{tabular}

Adapted from Nwajuiba et al. (2011) 
scheme. This will help farmers in the event the death of livestock due to flood, diseases and lack of water.

Developing improved livestock breeds: Government should increase support for livestock breeders in developing disease resistant species.

Building up measures to institutionalize Early Warning Systems: This will increase livestock farmers' ability to respond to climate related drought, flooding and disease impacts. Provision of potable water for livestock: Construction of dams, boreholes and wells are recommended to cater to the water needs of livestock management during the dry spells. Construction of embankment (dikes): This will help to reduce flooding caused by high rainfall events.

Culling of animals: Maintaining manageable herd size and removing diseased animals early will help reduce and control disease infestations.

Regular vaccination of livestock and cross border diseases surveillance: Vaccination can help reduce infections especially for migrating animals.

Encourage rainwater harvesting practices: This will help farmers adapt to shortage of water during dry spells and improve available forage on rangelands.

Other potential adaptation strategies involve land use decisions, animal feeding changes, genetic manipulation and alterations in species and/or breeds. In terms of mitigation, livestock is a substantial contributor to global non- $\mathrm{CO}_{2}$ greenhouse gas emissions. Mitigation opportunities involve altered land use for grazing and feed production, feeding practices, manure treatment and herd size reduction. In addition, strengthening institutions that promote markets and trade, as well as local support programs can help both mitigation and adaptation. Succinctly, a combination of nutritional manipulation, breeding and good management techniques is needed in order to achieve desirable results. Some of the nutritional approaches include:

\section{Forage species and stage of maturity}

Both factors play significant roles as Benchaar et. al 2001 found out that the substitution of Timothy hay with Lucerne decreases methane emission by $21 \%$ (expressed as \% digestible energy). Also, McCaughley et. al. (1999) observed that a 70:30 mix of Lucerne and grasses brought about $10 \%$ reduction in methane emission per unit product. It was concluded by the authors that the Methane reduction was due to intake of higher levels of lucerne intake which brought about a higher digestibility rate and increased passage of nutrients from the rumen. Furthermore, assuming there is an increased concentration of malate up to $3 \%$ of dry matter intake (DMI), the $\mathrm{CH}_{4}$ decrease might be explained by the organic acid (malate). This characteristic effect on methanogenesis, however, is not typical of all legumes; for instance Clover (white or red) did not differ from Ryegrass on $\mathrm{CH}_{4}$ emissions of growing Cattle (Beever et. al, 1985) or dairy Cattle (Van Dorland et. al, 2007). Inclusion of tannin rich legumes such as Sainfoin, Lotus, Sulla and certain shrubs in the diet also contributes to suppression of methanogenesis due to the presence of condensed tannins. Robertson and Waghorn (2002) observed that methane production from grazing dairy cows increased with forage maturity from $5 \%$ to $6.5 \%$ of Gross energy intake (in spring and summer, respectively). This was however not observed in other experiments; for example, cows grazing on a monospecific pasture of timothy at four stages of maturity over the grazing season (Pinares-Patin et. $a l, .2003)$. A decrease in $\mathrm{CH}_{4}$ with young fresh forages may be explained by a higher content of soluble sugars and linolenic acid. More generally, the correlation between forage quality and $\mathrm{CH}_{4}$ emissions is low (Pinares-Patin et. al, 2007). 


\section{Oyeniyi and Ewuola}

\section{Level and nature of concentrates}

An increase in the level of concentrates leads to a corresponding decrease in methane production as a proportion of energy intake or expressed by unit of animal product (milk and meat). Losses in methane appear to be relatively constant (6-7\% of gross energy intake) for diets containing up to $40 \%$ concentrates while a rapid decrease (2-3\% of gross energy intake) sets in when inclusion jerks up to $80 \%$. Significant modification of rumen physico-chemical conditions and microbial populations has been found to result from the replacement of structural carbohydrates in forages (cellulose, hemi-cellulose) with nonstructural carbohydrates in concentrates (starch and sugars). This is an offshoot of increased feed intake, higher rate of ruminal fermentation and accelerated feed turn over. A shift in volatile fatty acid production from acetate towards propionate occurs with the development of starch fermenting microbes which results in lower methane production. This is so because the relative proportion of ruminal hydrogen sources declines while hydrogen sinks increases. Concentrates rich in starch such as Maize, Wheat and Barley have a more important effect on low $\mathrm{CH}_{4}$ production than fibrous concentrates e.g. Beet pulp. Beauchemin and McGinn (2005) measured $\mathrm{CH}_{4}$ emissions from feedlot cattle fed starter and finishing diets containing maize (slowly degradable starch) or barley grain (rapidly degradable starch). Effect of grain source on $\mathrm{CH}_{4}$ emissions was conditioned by the production phase. Expressed on the basis of Gross Energy intake, $\mathrm{CH}_{4}$ emissions during the starter phase were not affected by grain source, whereas emissions were surprisingly less for the maize finishing diet than for the barley finishing period.

\section{Level, nature and presentation of lipids}

Dietary fat seems to be a promising nutritional alternative to depress methanogenesis without affecting other ruminal parameters. Martin et. al, (2009) summarised publications measuring invivo methane emissions where different lipid sources and forms were included in the diet. A total of 67 diets supplied with lipids, taken from 28 publications were kept for analysis; 29 results were obtained in open calorimetry chambers, 31 by the SF6 method and six by other methods; 33 were obtained on dairy cows, 13 on growing cattle and 16 on Sheep at maintenance and 5 on growing lambs. A mean decrease in $\mathrm{CH}_{4}$ of $3.8 \%$ was observed for every $1 \%$ supplemental fat added. It was hypothesised that the fatty acids' effects depended on their nature. A decrease by $52 \%$ has been shown with a supplement of $5.8 \%$ linseed oil whereas a decrease by $37 \%$ has been observed with $6 \%$ soyabean lipids (Jordan et al., 2006a). Data are less numerous for monounsaturated fatty acids such as oleic acid (from rapeseed; five data) and saturated fats (from tallow; eight data), but these supplements result in decreases by $2.5 \%$ and $3.5 \%$ per percentage unit of added lipids, respectively. A decrease of $30 \%$ has been observed when $12 \%$ tallow was added to the diet. Recently, Beauchemin et. al, (2009) reported that $\mathrm{CH}_{4}$ production in dairy cows was more affected by linseed and rapeseed ( $217 \%$ on average) than by sunflower seeds $(210 \%)$. Woodward et. al, (2006) investigated in vivo the effect of fish oil, rich in C20:5 and C22:6, in association with other oils and reported a minor effect on methanogenesis. A common effect for all lipid sources is that unlike other feed constituents such as forages and cereals they are not fermented in the rumen, and thus the decrease in fermented organic matter leads to a decrease in methane. Among common sources of lipids, coconut oil suffers from a possible negative effect of medium-chain fatty acids on human health, due to an increase in myristic acid in milk. In contrast, polyunsaturated fatty acids are 
considered beneficial on human health and their use in diets, which results in a limited increase of these fatty acids in milk and meat, could thus be proposed as a way for $\mathrm{CH}_{4}$ abatement provided that supplementation levels do not decrease feed efficiency or performance of animals.

\section{Ionophores and organic acids}

Ionophore antibiotics e.g. lasalocid and monensin are among the feed additives most commonly used to suppress methanogenesis and increase efficiency in ruminant production. Their mode of action often is directly on microbes wherein there is a shift in fermentation towards propionate production as against acetate. Ionophores also affect protozoa; the reduction and subsequent recovery in protozoal numbers perfectly matched $\mathrm{CH}_{4}$ abatement - up to $30 \%$ and restoration to previous level in a cattle trial (Guan et. al, 2006). The effect on emissions range from no changes to up to, $25 \%$ reductions with persistency being also variable among studies, from long- to shortterm (e.g. up to 6 months to a few days, respectively). These groups of additives are however not allowed in some countries including the European Union (where use of antibiotics has been banned since 2006). Organic acids (malate, fumarate and acrylate) have been assayed as diet additives. Fumarate and acrylate has been shown to be the most effective in vitro (Newbold et al., 2005). In contrast to the well-documented $\mathrm{CH}_{4}$ production response to organic acids in vitro, responses to dietary supplementation in vivo remain inconclusive and highly variable. An exceptional decrease in methane production, up to $75 \%$, has been shown with $10 \%$ encapsulated fumarate in the diet of lambs without any negative effect on animal growth (Wallace et. al, 2006). In contrast, encapsulated fumarate had no significant effect in another trial in dairy cows (McCourt et al., 2008). The high malate content in fresh forages (especially lucerne) at early growth stage, could lead to significant changes in rumen microbial fermentation.

Plant extracts (condensed tannins, saponins, essential oils): There is growing interest in the use of plant secondary compounds as a $\mathrm{CH}_{4}$ mitigation strategy. Preparations from plants are seen as a natural alternative to chemical additives that have been banned or that may be negatively perceived by consumers. Most trials with plant extracts have been done invitro and the response of these molecules on methanogenesis is highly variable. Most positive reports concern the chemical families of tannins and saponins, and the heterogenous group of compounds known as essential oils. For tannin-containing plants, the antimethanogenic activity has been attributed mainly to the group of condensed tannins. Two modes of action of tannins on methanogenesis have been proposed in vitro by Tavendale et. al, (2005): a direct effect on ruminal methanogens and an indirect effect on hydrogen production due to lower feed degradation. Many plants contain tannins, and these are often tropical shrub legumes. Animal trials with plants or extracts of condensed tannin-containing Lotus corniculatus, Lotus pedunculatus and Acacia mearnsii reduced $\mathrm{CH}_{4}$ production in small ruminants (sheep, alpaca, and goats) by up to $30 \%$ without altering digestibility (Pinares-Patin o et. al, 2003; Carulla et. al, 2005; Puchala et. al, 2005). More recently, Tiemann et. al, (2008) reported that the inclusion of the tannin-rich shrub legumes species Callinadra calothyrsus and Fleminga macrophylla in the diet reduced methane emissions in growing lambs by up to $24 \%$, but this was associated with reduced organic matter and fibre digestibility. Notwithstanding, the effect of condensed tannins cannot be generalised and testing is necessary as high-tannin sorghum silage (De Oliveira et. al, 2007) or 


\section{Oyeniyi and Ewuola}

condensed tannin extract from Schinopsis quebrachocolorado (Beauchemin et al., 2007) seem not to be effective in cattle. Many biologically active molecules present in essential oils have antimicrobial properties that are capable of affecting rumen fermentations. Among them, it has recently been shown that garlic oil and some of its components decreased $\mathrm{CH}_{4}$ production in vitro (Busquet et. al, 2005; Macheboeuf et. al, 2006). This was attributed to the toxicity of organosulphur compounds such as diallyl sulphide and allicin on methanogens. Additional research in vivo may be required to determine the optimal dose of the active compounds, to consider the potential adaptation of rumen microbes, the presence of residues in animal products as well as the potential antinutritional side-effects of such molecules. Palatability of these compounds could represent a practical issue. It has to be noted that sulphur-containing compounds are responsible for the described haemotoxic effects of onion and garlic on domestic herbivores (Rae, 1999; Pearson et. al, 2005).

Use of probiotics (Acetogens and yeast): The use of probiotics for the stimulation of rumen microbial populations capable of decreasing $\mathrm{CH}_{4}$ emissions remains a potentially interesting approach. Reductive acetogenesis is a natural mechanism of hydrogen utilisation that coexists with methanogenesis in the gastrointestinal tract of many animals. This pathway is the dominant one in several hindgutfermenting mammals (humans, rabbits, hamsters, rats) but also in foregut fermeners such as kangaroos (Klieve and Joblin, 2007). Acetate, the final product of the reaction, has an additional advantage of being a source of energy for the animal. However, in the rumen environment, acetogens are less numerous and efficient than methanogens in the competition for reducing equivalents. This is probably because acetogens need a higher concentration of hydrogen in the medium to reduce $\mathrm{CO}_{2}$ into acetate than that required for methanogens to reduce $\mathrm{CO}_{2}$ into $\mathrm{CH}_{4}$. In addition, the former reaction is thermodynamically less favourable (Weimer, 1998). Attempts to increase the natural rumen population of acetogens have been assayed but without success (Demeyer et. al, 1996). The use of acetogens as probiotics has also been tested by several authors with and without the addition of methanogen inhibitors to favour competition (Nollet et. al, 1998; Lopez et. $a l, 1999)$. Results, so far, have been either unsatisfactory or not conclusive. The recent isolation from diverse gut environments of new species (Klieve and Joblin, 2007) with presumably a higher affinity for hydrogen than previously tested acetogens could offer a renewed prospect for this approach. Live yeast, the most commonly used probiotic in ruminant production, has not been extensively tested for their effect on $\mathrm{CH}_{4}$ production (Chaucheyras-Durand et. al, 2008). However, yeasts are capable of showing great functional and metabolic diversity while some strains have been reported to decrease $\mathrm{CH}_{4}$ production in vitro (review of Newbold and Rode, 2006). These results are yet to be confirmed in vivo. The mechanisms by which yeasts decrease methanogenesis has been proposed to be by increasing microbial synthesis (review of Newbold and Rode, 2006) and by stimulating reductive acetogenesis (Chaucheyras et. al, 1995).

Gaughan and Cawdell-Smith (2015) reviewed studies of Climate Change impacts on livestock production and reproduction, concluding that findings largely indicated detrimental effects. They argue that adaptation in the form of genetic manipulation, breed change and/or species change may be needed. Silanikove (2000) indicates a switch to goats from cattle may be in order as goats have been found to be 
better adapted to hotter conditions; goats possess skillful grazing behavior; and the goat digestive system is more efficient as the rumen can serve as a fermentation vat and water reservoir. One should note that animal physiology and genetics limit an animal's adaptive capacity and that livestock breeders can alter traits to enhance adaptation (Gaughan and Cawdell-Smith, 2015). Breeds and species changes are also possible adaptations. Seo et al. (2010) examined climate influence on choices among five primary South American livestock species. Their results suggest that as Climate Change shifts toward hotter and drier conditions, producers would reduce beef cattle, dairy cattle, swine and poultry but increase sheep. Zhang et al. (2013) examined breed choice between Bos taurus, Bos indicus and composite breeds in Texas, finding summer heat stress influenced breed selection, with heat stress increasing favoring Bos indicus, while reducing Bos taurus and composite breeds. Wu (2015) examined how Climate Change influences the distribution of yak breeds in China, finding breed incidence has mainly shifted northward or westward (which is upward in elevation), partly as a response to the thermal conditions. Animal incidence is also affected by climate "extremes". Seo (2015) found in Australia that under high temperature conditions, sheep production increases in arid ecosystems while beef cattle remain about the same. The study also predicts under hotter and more arid $\mathrm{CC}$ futures that crops will decrease and numbers of beef cattle and/or sheep will increase. They indicate this shift is due to increased comparative advantage of raising livestock and reduced prevalence of livestock diseases.

For small-ruminants, Seo (2016) found that, as the monsoon climate intensifies, Indian farm households would increase goat numbers. Finally, regional adaptation will be in order as a shift in livestock species and incidence will alter needs for supporting industries providing feed, animal and feed transport, animal slaughter and meat packing and final product transport (Steinfeld et al, 2007).

To summarize, different ruminant livestock species or breeds respond differently to climate alterations and that livestock producers can adapt to Climate Change by changing species or breeds. A major mitigation strategy involves reducing herd size or composition. Thornton et al. (2009) mention that the only effective way to reduce livestock $\mathrm{CH} 4$ emissions in pastoral systems would be to reduce livestock numbers, as does Ripple et al. (2013). Also, Patra (2017) suggests that crossbreeding can be a mitigation strategy. For example, he estimates that if half of the indigenous cattle populations in India were replaced by crossbred cattle, then the carbon footprint of milk production could drop by $30 \%$ due to increased productivity.

Concepts for alleviating heat stress by environmental management have been narrowed to two strategies: altering the environment by providing shade in order to decrease exposure to solar radiation and/or evaporative cooling; secondly, directly cooling by using sprinkler or soakers to wet the animal. The implementation of a shade structure decreases solar heat load on animals. The environment surrounding the animals can then be further improved via increasing convection with fans or to decrease air temperature by evaporative cooling or by directly cooling using sprinklers and soakers.

\section{Conclusion \\ Recommended roles for the federal government include:}

There should be research and development of appropriate technology for agriculture, including biotechnology to continually increase the yield of agricultural production as well as find markets for the products. 


\section{Oyeniyi and Ewuola}

Table 2: Policies, programs, adaptation options addressed, implementing agency and cost for the livestock sub-sector

\begin{tabular}{|c|c|c|c|c|c|}
\hline $\begin{array}{l}\text { Recommended } \\
\text { Climate Change } \\
\text { Adaptation (CCA) } \\
\text { Policy Options }\end{array}$ & $\begin{array}{l}\text { Proposed CCA } \\
\text { Programmes }\end{array}$ & $\begin{array}{l}\text { Eco-zones } \\
\text { Addressed }\end{array}$ & $\begin{array}{l}\text { CCA options } \\
\text { addressed by } \\
\text { proposed policies } \\
\text { \& progs. }\end{array}$ & Implementation Agency & $\begin{array}{l}\text { Estimated } \\
\text { Costs (N) }\end{array}$ \\
\hline $\begin{array}{l}\text { Comprehensive } \\
\text { review of national } \\
\text { agricultural policies } \\
\text { on pest and disease } \\
\text { control; agricultural } \\
\text { credit schemes }\end{array}$ & $\begin{array}{l}\text { Mainstream CCA } \\
\text { in animal disease } \\
\text { control \& } \\
\text { surveillance } \\
\text { programme } \\
\text { Comprehensive } \\
\text { review of } \\
\text { National } \\
\text { Agricultural } \\
\text { Credit Grant } \\
\text { Scheme }\end{array}$ & All & $\begin{array}{l}\text { Regular vaccination } \\
\text { of livestock and } \\
\text { cross-border } \\
\text { diseases } \\
\text { surveillance } \\
\text { Culling of Animals } \\
\text { Intensive livestock } \\
\text { keeping }\end{array}$ & $\begin{array}{l}\text { Farmers and Government } \\
\text { Agencies }\end{array}$ & 200 Million \\
\hline $\begin{array}{l}\text { Maintenance of } \\
\text { existing large dams } \\
\& \text { developing small } \\
\text { dams, provision of } \\
\text { borehole for } \\
\text { livestock farmers' } \\
\text { communities as a } \\
\text { further effort in } \\
\text { implementing } \\
\text { National Agricultural } \\
\text { Policy on Water } \\
\text { Resources }\end{array}$ & $\begin{array}{l}\text { Mainstream CCA } \\
\text { in River Basin } \\
\text { Development } \\
\text { Programmes } \\
\text { Encourage } \\
\text { rainwater } \\
\text { harvesting by } \\
\text { Agricultural } \\
\text { Extension agents }\end{array}$ & $\begin{array}{l}\text { All Rainforests/ } \\
\text { Coastal Zones }\end{array}$ & $\begin{array}{l}\text { Provision of potable } \\
\text { waterfor livestock } \\
\text { Constructionof } \\
\text { embankments } \\
\text { Encourage } \\
\text { rainwater harvesting } \\
\text { practices }\end{array}$ & $\begin{array}{l}\text { River Basin Development } \\
\text { Authorities } \\
\text { NationalFadama } \\
\text { Programme } \\
\text { Communities } \\
\text { NGOs }\end{array}$ & 1 Billion \\
\hline $\begin{array}{l}\text { Increase national } \\
\text { coordination of } \\
\text { Agricultural } \\
\text { Research Policy }\end{array}$ & $\begin{array}{l}\text { Mainstream CCA } \\
\text { in livestock } \\
\text { development } \\
\text { programme of the } \\
\text { Federal Ministry } \\
\text { of Agriculture }\end{array}$ & All & $\begin{array}{l}\text { Develop improved } \\
\text { hybrids of livestock } \\
\text { species }\end{array}$ & $\begin{array}{l}\text { Livestock Research } \\
\text { Institutes }\end{array}$ & 500 Million \\
\hline $\begin{array}{l}\text { Develop policy on } \\
\text { Early Warning } \\
\text { Systems for floods \& } \\
\text { disease outbreaks }\end{array}$ & $\begin{array}{l}\text { Programmes on } \\
\text { early warning } \\
\text { systems for floods } \\
\text { and other climate } \\
\text { related disasters } \\
\text { including disease } \\
\text { outbreaks } \\
\text { Encourage } \\
\text { scientific and } \\
\text { indigenous } \\
\text { knowledge on } \\
\text { weather } \\
\text { forecasting }\end{array}$ & All & $\begin{array}{l}\text { Building up } \\
\text { measures to } \\
\text { institutionalize } \\
\text { Early Warning } \\
\text { Systems for rainfall, } \\
\text { drought, floods, \& } \\
\text { disease outbreaks }\end{array}$ & $\begin{array}{l}\text { Nigerian Meteorological } \\
\text { Agency (NIMET) \& its } \\
\text { affiliated agencies } \\
\text { Communities }\end{array}$ & 500 Million \\
\hline $\begin{array}{l}\text { Comprehensive } \\
\text { Review of } \\
\text { Agricultural Policy on } \\
\text { Insurance }\end{array}$ & $\begin{array}{l}\text { Mainstream CCA } \\
\text { in Nigerian } \\
\text { Agricultural } \\
\text { Insurance }\end{array}$ & All & $\begin{array}{l}\text { Greater supportfor } \\
\text { Insurance }\end{array}$ & $\begin{array}{l}\text { Nigerian Agricultural } \\
\text { Insurance Corporation } \\
\text { (NAIC) }\end{array}$ & 250 Million \\
\hline
\end{tabular}

Adapted from Nwajuiba et al. (2011) 


\section{A review of strategies aimed at adapting livestock to volatile climate conditions in Nigeria}

Table 3: Recommended Climate Adaptation and Mitigation Strategies for livestock reared in Developing Countries

\begin{tabular}{|c|c|c|}
\hline Adaptation/Mitigation & Section & Developing Countries \\
\hline \multirow[t]{4}{*}{ Adaptation } & Feed and Land Resources & $\begin{array}{l}\text { Animal feed production: } \\
\text { - Farm-level production adjustments } \\
\text { - Introduce/revise insurance/credit schemes; enhance } \\
\text { income diversification opportunities } \\
\text { - Institutional changes such as introducing subsidies, } \\
\text { strengthening markets and trade } \\
\text { - Adopt new technologies } \\
\text { Land use: } \\
\text { - A move to livestock out of cropping } \\
\text { - Increase the joint production of crops and animals }\end{array}$ \\
\hline & Genetics/Breeds/Species & $\begin{array}{l}\text { Ruminants: } \\
\text { - Switch from cattle to goats } \\
\text { - Increase sheep } \\
\text { - Increase goats } \\
\end{array}$ \\
\hline & Trade and Local Institutions & $\begin{array}{l}\text { Trade: } \\
\text { - Trading can induce adjustments in regional } \\
\text { production } \\
\text { Local Institutions: } \\
\text { - Local agriculture trad itional knowledge can be of } \\
\text { essential help }\end{array}$ \\
\hline & Disease & $\begin{array}{l}\text { - Increase Disease Surveillance by improving Local } \\
\text { and National Quarantine Services } \\
\text {-Enforce incorporation of strict biosecurity measures } \\
\text { in farms } \\
\text { - Select animal breeds resistant to ticks, drought, } \\
\text { typanosomosis etc }\end{array}$ \\
\hline \multirow[t]{6}{*}{ Mitigation } & Land Resources & $\begin{array}{l}\text { Land Use: } \\
\text { - Better management of existing protected area } \\
\text { - Facilitate eco-services payment mechanisms } \\
\text { - Improve grazing management } \\
\text { - Legume sowing on pasturelands } \\
\text { Land Use Change: } \\
\text { - Intensify cattle ranching to avoid deforestation } \\
\text { - Transition towards more efficient livestock } \\
\text { production systems }\end{array}$ \\
\hline & Fertilization & $\begin{array}{l}\text { Nitrogen efficiency: } \\
\text { - Increase Nitrogen efficiency during both feed } \\
\text { production and livestock assimilation stages }\end{array}$ \\
\hline & Enteric Fermentation & $\begin{array}{l}\text { Nutrition: } \\
\text { - Treat crop byproducts with urea in mixed } \\
\text { crop-livestock systems }\end{array}$ \\
\hline & Manure Management & $\begin{array}{l}\mathrm{CH}_{4} \text { (Methane) } \\
\text { - Reduce exposure of manure to water }\end{array}$ \\
\hline & $\begin{array}{l}\text { Livestock Numbers, Breeds } \\
\text { and Mix }\end{array}$ & $\begin{array}{l}\text { - Decrease herd size } \\
\text { - Increase feeding efficiency, especially for swine and } \\
\text { poultry } \\
\text { Breeds and Mix: }\end{array}$ \\
\hline & Market trade & $\begin{array}{l}\text { Stnpply. } \\
\text { - Shifts in regional production } \\
\text { Demand: } \\
\text { - Shifts in dietary preferences }\end{array}$ \\
\hline
\end{tabular}

Adapted from Zhang et al. (2017) with slight modifications 


\section{Oyeniyi and Ewuola}

Also, there should be establishment and maintenance of an effective and robust national animal quarantine service. There should be establishment of an agricultural insurance scheme and collaboration with state and local governments for a welltrained and effective agricultural extension service delivery to all farmers. In addition there should be Government support to inputs, supply and distribution including improved breeds; and playing a larger role in the control of livestock pests and diseases of national and international significance.

\section{Recommended roles for state governments} include:

The promotion of all livestock products through the provision of more effective extension service as well as promotion of the production of inputs required to support livestock production. Also, there should be promotion of ranch development and access to water for livestock; contribute to training and manpower development. The promotion of the control of animal pests and diseases and promotion of appropriate institutions for administering credit to smallholders should also be included within the state Government's purview. There should also be maintenance of buffer stocks of agricultural commodities and investments in rural development infrastructure including rural roads and water supplies.

\section{Recommended roles for local governments include:}

There should be provision of an effective agricultural extension service and rural infrastructure. The mobilization of farmers for accelerated agricultural and rural development through cooperative organizations, local institutions and the communities and co-ordination of data collection at the primary levels should be done.

Recommended roles for the private sector include:

Investment should be encouraged in all aspects of livestock production such as livestock product storage, processing and marketing. There should also be provision of a favourable investment climate for the private sector in livestock input supply and distribution. In addition, production of commercial breeds under government certification and quality control should be encouraged. There should be provision of enterprise-specific rural infrastructure and rendering of support for research in all aspects of livestock production.

\section{References}

Beauchemin, K. A. and McGinn, S. M. 2005. Methane emissions from feedlot cattle fed barley or corn diets. Journal of Animal Science 83: 653-661.

Beauchemin, K. A., McGinn, S. M. and Petit, H. V. 2007. Methane abatement strategies for cattle: lipid supplementation of diets. Canadian Journal of Animal Science 87:431-440.

Beauchemin K. A., McGinn S. M., Benchaar C. and Holtshausen L. 2009. Crushed sunflower, flax, or canola seeds in lactating dairy cows' diets: effects on methane production, rumen fermentation, and milk production. Journal of Dairy Science 92:2118-2127.

Beever, D. E., Thomson, D. J. , Ulyatt, M. J., Cammell, S. B. and Spooner, M. C. 1985. The digestion of fresh perennial (Lolium perenne L. cv. Melle) and white clover (Trifolium repens L. cv. Blanca) by growing Cattle fed indoors. British Journal of Nutrition 54: 763-775.

Benchaar, C., Pomar, C. and Chiquette, J. 2001. Evaluation of dietary strategies to reduce methane production in ruminants: a modelling approach. Canadian Journal of Animal Science 
A review of strategies aimed at adapting livestock to volatile climate conditions in Nigeria

81:563-574.

Busquet, M., Calsamiglia S., Ferret A., Carro M.D. and Kamel C. 2005. Effect of garlic oil and four of its compounds on rumen microbial fermentation. Journal of Dairy Science 88: 4393-4404.

Carulla, J. E., Kreuzer, M., Machmu, ller A. and Hess, H. D. 2005. Supplementation of Acacia mearnsii tannins decreases methanogenesis and urinary nitrogen in forage-fed Sheep. Australian Journal of Agricultural research 56: 961-970.

Chaucheyras. F., Fonty, G., Bertin, G. and Gouet, P. 1995. In vitro Hydrogen utilization by a ruminal acetogenic bacterium cultivated alone or in association with an archaea methanogen I stimulated by a probiotic strain of Saccharomyces cerevisiae. Applied and Environmental Microbiology 61:3466-3467.

Chaucheyras-Durand, F., Walker N. D. and Bach, A. 2008. Effects of active dry yeasts on the rumen microbial ecosystem: past, present and future. Animal Feed Science and Technology 145: 5-26.

De Oliveira, S. G. , Berchielli T. T. , Pedreira M. D. , Primavesi O. , Frighetto R. and Lima M.A.

2007. Effect of tannin levels in sorghum silage and concentrate supplementation on apparent digestibility and methane emission in beef Cattle. Animal Feed Science and Technology 135: 236-248.

Dourmad, J., Rigolot, C., and Hayo van der Werf, 2008. Emission of Greenhouse Gas: Developing management and animal farming systems to assist mitigation. Livestock and Global Change conference proceeding. May 2008,
Tunisia.

Gaughan, J., Cawdell-Smith, A.J. 2015. Impact of Climate Change on Livestock Production and Reproduction. In Climate Change Impact on Livestock: Adaptation and Mitigation; Sejian, V., Gaughan, J., Baumgard, L., Prasad, C., Eds.; Springer: New Delhi, India, pp. 51-60, ISBN 978-81322-2264-4.

Guan, H. , Wittenberg, K. M. , Ominski, K. H. and Krause, D. O. 2006. Efficacy of ionophores in Cattle diets for mitigation of enteric methane. Journal of Animal Science 84: 1896-1906.

Macheboeuf, D. , Lassalas, B. , Ranilla, M. J., Carro, M. D. and Morgavi, D.P. 2006. Dose- response effect of diallyl disulfide on ruminal fermentation and methane production in-vitro. Reproduction Nutrition Development 46: S103.

Martin C., Morgavi D. P. and Doreau M. 2009. Methane mitigation in ruminants: from microbe to the farm scale. Animal 43: pp 351-365.

McCaughey W. P., Wittenberg K. and Corrigan D. 1999. Impact of pasture type on methane production by lactating Beef Cows. Canadian Journal of Animal Science 79: 221-226.

McCourt A. R., Yan T., Mayne S. and Wallace J. 2008. Effect of dietary inclusion of encapsulated fumaric acid on methane production from grazing dairy cows. In Proceedings of the British Society of Animal Science, 31 March-2 April 2008, Scarborough, UK, p. 64.

Newbold, C. J and Rode, L. M. 2006. Dietary additives to control methanogenesis in the rumen. In Greenhouse gases and animal agriculture: an update (ed. C.R 


\section{Oyeniyi and Ewuola}

Soliva, Takahashi J. and Kreuzer M.), Elsevier International Congress Series 1293, pp. 138-147. Elsevier, Amsterdam, Netherlands.

Patra, A.K. 2017. Accounting methane and nitrous oxide emissions, and carbon footprints of livestock food products in different states of India. J. Clean. Prod. 162, 678-686.

Pinares-Patino, C. S., Baumont, R. and Martin, C. 2003. Methane emissions by Charolais Cows grazing a monospecific pasture of timothy at four stages of maturity. Canadian Journal of Animal Science 83: 769-777.

Pinares-Patino, C. S., D'Hour P., Jouany, J. P. and Martin, C. 2007. Effects of stocking rate on methane and carbon dioxide emissions from grazing cattle. Agriculture, Ecosystems and Environment 121: 30-46.

Pinares-Patino, C. S., Ulyatt, M. J., Waghorn G. C., Lassey, K. R., Barry, T. N., Holmes, C. W.

and Johnson, D. E. 2003. Methane emission by alpaca and sheep fed on lucerne hay or grazed on pastures of perennial ryegrass/white clover or birdsfoottrefoil. Journal of Agricultural Science 140: 215-226.

Puchala, R., Min, B. R., Goetsch, A. L. and Sahlu, T. 2005. The effect of condensed tannin- containing forage on methane emission by goats. Journal of Animal Science 83, 182-186.

Ripple, W. J., Smith, P., Haberl, H., Montzka, S. A., McAlpine, C., Boucher, D. H. 2013. Ruminants, climate change and climate policy. Nat. Climate Change. 4, 2-5.

Seo, S. N., McCarl, B. A., Mendelsohn, R.
2010. From beef cattle to sheep under global warming $\square$ An analysis of adaptation by livestock species choice in South America. Ecol.Econ. 69, 2486-2494.

Seo, S. N. 2015. Adapting to extreme climates: Raising animals in hot and arid ecosystems in Australia. Int. J. Biometeorol. 2015, 59, 541-550.

Seo, S. N. 2016. Untold Tales of Goats in Deadly Indian Monsoons: Adapt or Rain-Retreat under Global Warming $\square J$. Extreme Events 3, 1650001

Silanikove, N. 2000. The physiological basis of adaptation in goats to harsh environments. Small Rumin. Res. 35, 181-193.

Steinfeld, H., Wassenaar, T. 2007. The Role of Livestock Production in Carbon and Nitrogen Cycles. Annu. Rev. Environ. Resources 32, 271-294.

Tavendale, M. H., Meagher, L. P. , Pacheco, D. , Walker, N. , A t t w o od, G . T. a n d Sivakumaran, S. 2005. Methane production from in vitro rumen incubations with Lotus pedunculatus and Medicago sativa, and effects of extractable condensed tannin fractions on methanogenesis. Animal Feed Science and Technology 123-124: 403-419.

Tiemann, T. T. , Lascano, C. E. , Wettstein, H. R. , Mayer, A. C. , Kreuzer, M. and Hess, H. D. 2008. Effect of the tropical tannin-rich shrub legumes Calliandra calothyrsus and Flemingia macrophylla on methane emission and nitrogen and energy balance in growing lambs. Animal 2: 790-799.

Van Dorland, H. A., Wettstein, H. R., 
Leuenberger, $H$. and Kreuzer, $M$. 2007. Effect of supplementation of fresh and ensiled clovers to ryegrass on nitrogen loss and methane emissions of dairy cows. Livestock Science 111: 57-69.

Waghorn, G. C. 2007. Beneficial and detrimental effects of dietary condensed tannins for sustainable Sheep and Goat production: progress and challenges. Animal Feed Science and Technology 147: 116-139.
Zhang, Y.W., Hagerman, A.D., McCarl, B.A. 2013. Influence of climate factors on spatial distribution of Texas cattle breeds. Climate Change 118, 183-195.

Zhang, Y.W., McCarl, B.A., Jones, J. P. H. 2017 An Overview of Mitigation and Adaptation Need and Strategies for the Livestock Sector. Climate 5 (95), 9-10.

Received: $12^{\text {th }}$ October, 2020 Accepted: $15^{\text {th }}$ February, 2021 